\title{
Occupational and Environmental Toxicology of Mercury and Its Compounds
}

\author{
Hiroshi SATOH \\ Environmental Health Sciences, Tohoku University School of Medicine \\ 2-1 Seiryo-machi, Aoba-ku, Sendai 980-8575, Japan \\ Received February 10, 2000 and accepted February 14, 2000
}

\begin{abstract}
Mercury exists in various chemical forms. The important forms from a toxicological viewpoint are the metallic form, also called the elemental form, the divalent inorganic forms and methylmercury compounds. Elemental $\left(\mathbf{H g}^{0}\right)$ mercury has a high vapor pressure and the vapor causes a number of cases of poisoning via inhalation. Classical mercury poisoning is characterized by a triad of signs, namely tremors, erethism and gingivitis. Mercurial erethism, which is characterized by behavioral and personality changes such as extreme shyness, excitability, loss of memory, and insomnia are also observed. Recently, the effects of mercury exposure at levels around $0.05 \mathrm{mg} / \mathrm{m}^{3}$ or lower have been of concern and may include minor renal tubular damage, increased complaints of tiredness, memory disturbance and other symptoms, subclinical finger tremor, abnormal EEG by computerized analysis and impaired performance in neurobehavioral or neuropsychological tests. Abnormal gait, dysarthria, ataxia, deafness and constriction of the visual field are typical of the symptoms of methylmercury poisoning observed in Minamata and Iraqi outbreaks, as well as in occupational methylmercury poisoning cases. Furthermore, an infant born to a mother with excessive methylmercury consumption showed various neurological disturbances and delayed development. Since several populations are believed to be still exposed to methylmercury through the consumption of fish and sea mammals, neurobehavioral deviations in children of these populations have recently been investigated.
\end{abstract}

Key words: Mercury, Mercury vapor, Methylmercury, In utero exposure, Developmental effects, Neurobehavioral effects

\section{Introduction}

Mercury exists in various chemical forms. The important forms from a toxicological viewpoint are the metallic form, also called the elemental form, the divalent inorganic forms and methylmercury compounds.

Metallic or elemental $\left(\mathrm{Hg}^{0}\right)$ mercury is a liquid at room temperature and has a high vapor pressure. Thus, mercury vapor causes a number of cases of poisoning via inhalation.

Mercury ions occur in two oxidation states: mercurous mercury $\left(\mathrm{Hg}^{+}\right)$and mercuric mercury $\left(\mathrm{Hg}^{++}\right)$. However, the mercurous ion has a unique structure with two atoms having an overall charge of $++^{1)}$. Therefore the bond between these two atoms breaks easily to form elemental and divalent inorganic mercury.

Most compounds of mercuric mercury are corrosive, as reflected in the generic name of mercuric chloride i.e., corrosive sublimate. The compounds of mercuric mercury are also toxic when absorbed by living organisms, though absorption is poor compared to that of organic mercury compounds like alkyl mercurials ${ }^{2}$. Mercuric fulminate is explosive in its dry state.

Divalent mercury is covalently linked to a carbon atom to form organic mercury compounds. Methyl mercury 
$\left(\mathrm{CH}_{3} \mathrm{Hg}^{+}\right)$, thus formed, is extremely toxic and readily absorbed from the gastrointestinal tract of humans and animals ${ }^{3}$. Dialkylmercury (RHgR) is also formed and such compounds have a unique liquid state and volatility.

In other organic mercury compounds, such as aryl and alkoxyalkyl mercury compounds, the carbon mercury bond is less stable than that of methylmercury ${ }^{4-7)}$. The toxicity of these compounds is due to the released divalent mercury.

In this review the two major forms of mercury, elemental mercury (mainly in vapor form) and methylmercury compounds are examined, as humans are still exposed to elemental mercury and methyl mercury in occupational and environmental settings.

\section{Human Exposure}

\section{Mercury vapor}

Metallic mercury was known in ancient times and was named "quick silver" by Aristotle due to its liquid nature at room temperature ${ }^{1)}$. In Almaden, Spain, mining of cinnabar (mercuric sulfide) has been continuous since the Roman era. The ore is so rich that metallic mercury deposits naturally onto the surface of the ore rocks. Since only slaves and criminals worked the mines, the toxicity of metallic mercury was most likely already established. At room temperature, the vapor concentration easily exceeds the current threshold limit of $0.025 \mathrm{mg} / \mathrm{m}^{3}$, thus miners were exposed to mercury vapor via inhalation.

The first large-scale occupational mercury poisoning is believed to have occurred when the great statue of Buddha of Nara was built in the 8th century, in Japan. Gold-mercury amalgam was applied to the statue and the mercury evaporated off by heating to leave a thin layer of gold on the surface, in the process exposing workers to toxic levels of mercury vapor.

Surprisingly, the same type of exposure and consequent mercury poisoning used to occur, until recently, in the gold mines and purification plants in the Amazon basin, Philippines, Indonesia and South Africa ${ }^{8,9}$. Liquid mercury was used to extract and purify the gold and the gold-mercury amalgam then heated leaving virtually pure gold. In addition to exposure of workers to toxic levels of mercury vapor, the process released tons of mercury into the atmosphere. The released mercury was naturally converted into methyl mercury thereby causing environmental pollution and damage to eco-systems ${ }^{10-12)}$.

In the middle ages, alchemists used mercury extensively due to its ability to form amalgams, and unsuccessfully tried to turn mercury into gold. During this period, two mercury compounds, mercurous chloride (calomel) and mercuric chloride (corrosive sublimate) were first produced ${ }^{1}$.

More recently and before the 20th century, mercuric salts were long used to make felt hats, as these salts were found to be highly effective in making animal hair sticky, resulting in high quality felt ${ }^{1}$. Since the felt was heated to make the hat, workers were exposed to mercury vapor generated during the process. The "Mad Hatter" in "Alice in Wonderland" is considered to represent an example of chronic mercury poisoning.

Metallic mercury is also used as the cathode in a chloralkaline plant where sodium chloride solution is electrolyzed to make sodium hydroxide ${ }^{13)}$. This process is still used in several countries in Europe. The workers are exposed to mercury vapor, although the concentrations are lower than the aforementioned levels encountered after heating gold-mercury amalgams. The chloralkaline plant releases mercury into the environment combined with cooling water.

Mercury has been used for various medicinal purposes, not always successfully. For instance, the treatment for syphilis sometimes resulted in severe poisoning ${ }^{14)}$, and calomel has even been used in children's teething powder for unknown reasons.

People are still exposed to mercury vapor in the form of the silver-mercury amalgam used to fill dental caries ${ }^{15)}$. Although the use of such dental amalgam is rare in Japan, in the United States and several European countries this is still the predominant amalgam. Chewing and brushing increases the release of mercury vapor from the amalgam and vapor thus generated is inhaled ${ }^{16-18)}$. The amount of mercury inhaled per day is estimated to be $2.5-17.5 \mu \mathrm{g}$.

\section{Methyl mercury}

Organic mercury compounds including methylmercury have been commercially produced since 1930 . The use of organic mercury compounds in chemical research, however, dates back to 1863 . Some of these mercurials break down easily into inorganic mercury. Consequently, the toxic effects of these compounds are similar to those of inorganic mercury compounds.

The alkyl mercury compounds, in particular methylmercury, possess a mercury carbon bond much stronger than those found in the other organic mercury compounds. Thus, they have unique toxic properties. Two laboratory technicians were poisoned with dimethyl mercury in $1866^{19)}$. They complained of numbness of the hands, deafness, poor vision and sore gums. Slow and indistinct speech was noted. They became restless and comatose and 
finally died.

Most of these signs and symptoms resemble those observed in acute Minamata disease (described below). However, sore gums and salivation are symptoms of mercury vapor poisoning, supposedly the result of co-existing metallic mercury produced by the breakdown of dimethyl mercury.

Thereafter, sporadic cases of organic mercury poisoning have been reported. Organic mercury compounds have been used primarily for seed dressing, and thus most victims have been workers in chemical manufacturing plants, and farmers and members of their families who have accidentally ingested dressed seeds. Some victims ate the meat of domestic animals fed dressed plants.

\section{Minamata disease}

Minamata disease is the name used to describe the methylmercury poisoning that occurred among the people living along Minamata Bay in Kyushu, Japan in the 1950's and 60 's $\mathrm{s}^{20)}$. The source of methylmercury was effluent from a chemical company where mercury was used as a catalyst in the production of acetaldehyde. The methylmercury concentrated in the food chain, resulting in sufficiently high concentrations in the villagers' staple diet of fish and shellfish to cause mercury poisoning. This type of exposure to methylmercury was highly uncommon and unusual, although the number of victims eventually certified with Minamata disease was over 2,200.

Another outbreak of methylmercury poisoning occurred in Niigata prefecture in 1965. Dubbed Niigata Minamata disease, this outbreak was also caused by acetaldehyde plant effluent. Approximately 700 patients resulted ${ }^{20)}$.

In the Minamata Bay area, infants began to manifest a severe disease resembling cerebral palsy ${ }^{21}$. The mothers of these children had consumed contaminated fish and shellfish during pregnancy. Fetuses were exposed to methylmercury in utero as methylmercury easily crosses the placental barrier and premature blood-brain barrier of the fetuses, affecting the developing fetal central nervous system. The mothers of these children had seemed healthy or displayed only mild symptoms such as numbness around the lips at the time their children were confirmed to have fetal Minamata disease ${ }^{22}$. Although the mothers developed further symptoms later, fetuses are believed to be much more sensitive to methylmercury than adults.

In the Niigata Minamata disease episode, only one baby with fetal Minamata disease was born, largely because the local authorities recommended that residents of child bearing age with possible exposure to methylmercury take contraceptive measures.

\section{Methylmercury poisoning in Iraq}

Since organic mercury compounds were first used as seed dressings, poisoning by eating dressed wheat grain has repeatedly occurred. In Iraq, three epidemic poisonings have been reported: one in 1955-1956, another in 1959-1960, and the third and largest outbreak in 1971-1972.

These outbreaks were caused by the distribution of seed grain treated with methylmercury ${ }^{23}$. Rural people consumed the grain by using it to make homemade bread, instead of planting the seeds. The total number of victims was 6530 , including 459 deaths. There were also some fetal cases, in which the mothers ate contaminated bread during pregnancy thereby exposing the fetuses to methylmercury in utero ${ }^{24}$. After birth, the infants were examined for physical and mental development ${ }^{25-27}$. The developmental data were statistically analyzed to establish a dose-response relationship between the exposure doses and the effects (developmental retardation). The exposure dose was determined by the peak mercury concentration in maternal hair during pregnancy.

The mercury concentration in hair (microgram $\mathrm{Hg} / \mathrm{g}$ hair) is proportionally higher than the blood mercury concentration (microgram $\mathrm{Hg} / \mathrm{L}$ blood) by $250-300$ times $^{28,29)}$. Mercury is included in a hair strand from the very beginning of the hair's growth, and is retained for the life of the strand. Thus, the concentration of mercury in the root of hair indicates the most recent blood mercury concentration and the distance from the root can be converted to the length of time from exposure. Assuming that hair grows approximately $1 \mathrm{~cm} /$ month, hair strands were cut into $1 \mathrm{~cm}$ long segments from the root and the mercury concentration in each portion determined, thus providing the blood mercury concentration for each month. Fortunately, Iraqi women usually have long hair, allowing researchers to map the exposure history of each individual during the entire gestation period.

\section{Current exposure to methylmercury}

Mercury is methylated in the environment ${ }^{30}$, whether the origin is natural or anthropogenic. Methylmercury is considered to be formed primarily via bacterial activity. Thus formed, methylmercury enters the aquatic food chain to become the predominant dietary source of mercury in humans. The highest levels of methylmercury are found in predatory fish and sea mammals. Therefore, fish-eating populations are exposed to methylmercury ${ }^{31}$.

Since fetuses are much more sensitive to methylmercury than adults, as shown in the outbreaks in Minamata and Iraq, the possible effects of in utero exposure to methylmercury have been examined in several places such as New Zealand, the Seychelles and the Faeroe Islands. 


\section{Health Effects}

\section{Effects of mercury vapor exposure}

The signs and symptoms observed in mercury vapor poisoning differ depending on the level and duration of exposure.

When exposure is extremely heavy (approximately 5-10 $\mathrm{mg} / \mathrm{m}^{3}$ or may be higher) such as direct inhalation of mercury vapor generated from heating metallic mercury, erosive bronchitis and bronchiolitis will occur in a few hours. Interstitial pneumonitis will then develop followed by respiratory distress. Excitability and tremors, indicating the central nervous system has been affected, may also be seen. If the amount of mercury inhaled is large enough, renal failure will develop.

Such an accidental exposure took place recently in Japan at a chemical factory that was producing sulfuric acid ${ }^{32}$. Workers replaced pipes of a tubular heat exchange apparatus using gas burners. Since sludge inside the pipes contained mercury, mercury vapor was generated during the operation. The workers were exposed to mercury vapor and became ill, and tragically a few died of respiratory distress associated with renal failure.

Moderate and repeated exposure (lower than a few $\mathrm{mg}$ / $\mathrm{m}^{3}$, but higher than $0.05 \mathrm{mg} / \mathrm{m}^{3}$ ) causes classical mercury poisoning, which is characterized by a triad of signs, namely, tremor, erethism and gingivitis. Mercurial erethism, which is characterized by behavioral and personality changes such as extreme shyness, excitability, loss of memory, and insomnia are also observed. Gingivitis and excessive salivation are the most common signs.

Lower and long lasting exposure causes micromercurialism, which is characterized by weakness, fatigue, anorexia, loss of weight, and disturbances in the gastrointestinal tract.

Recently, the effects of much lighter mercury vapor exposure [around the previous TLV $\left(0.05 \mathrm{mg} / \mathrm{m}^{3}\right)$ ] have been investigated, with the following results:

1) Minor renal tubular effects indicated by increased urinary excretion of $\beta$-galactosidase ${ }^{33)}$ and $N$-acetyl- $\beta$ glucosaminidase $(\mathrm{NAG})^{34,35}$ have been noted.

2) Increased complaints of tiredness, memory disturbance and other symptoms have been reported in selfadministered questionnaires ${ }^{34)}$

3) Subclinical finger tremor has been observed using apparatus analyses ${ }^{33,36,37)}$

4) Slower and attenuation of power spectrum of EEG ${ }^{38)}$

5) Impaired performance in neurobehavioral or neuropsychological tests ${ }^{39)}$

\section{Residual or remote effects of mercury vapor Inhalation}

More recently, residual effects due to previous exposure have become a concern. Workers with a peak urinary mercury concentration higher than $0.6 \mathrm{mg} / \mathrm{L}$ have shown neurobehavioral disturbances 20 to 35 years post-exposure ${ }^{40)}$. Among ex-mercury miners in Japan, neurobehavioral disorders related to previous exposure that ceased more than 17 years ago have been reported ${ }^{41}$. Besides neurobehavioral disturbances, an increase in lymphocyte micronuclei stimulated by phytohemagglutinin was also observed ${ }^{42}$. The increase positively correlated with indices of previous exposure.

Clearly the effects of mercury vapor exposure last long after cessation of exposure, although typical symptoms and signs, such as tremor, gingivitis and salivation, usually disappear quickly. Mechanisms of long-lasting or remote effects, however, have not been investigated. There are several possible explanations: The first is that the damage caused by mercury vapor exposure remains for a long period of time. The second is that mercury remains in the body where it continues to cause adverse effects. The third is that previous exposure somehow stimulates aging, which causes poorer neurobehavioral performance. More complex explanations and combinations of these possibilities are of course conceivable.

\section{Effects of methylmercury exposure}

Previous experiences and animal experiments have shown that CNS functions are affected most by methylmercury exposure as opposed to the other forms of mercury.

In 1940, Hunter, Bomford and Russel reported four cases of methylmercury poisoning in a factory where fungicidal dusts were manufactured without the use of an enclosed apparatus ${ }^{19}$. The symptoms were severe generalized ataxia, dysarthria and constriction of the visual field. They noted that the characteristic symptoms of mercury vapor poisoning, with the exception of tremors, were not observed. One of the victims suffered from symptoms (mainly ataxia) for 15 years after exposure had ceased.

At patient necropsy, generalized ataxia was referable to cerebellar cortical atrophy, selectively involving the granulecell layer of the neocerebellum ${ }^{43)}$. The concentric constriction of the visual fields was correlated with bilateral cortical atrophy around the calcarine fissures. This was reported in 1954 and later methylmercury poisoning was referred to as Hunter-Russel syndrome.

In the Minamata disaster, abnormal gait, dysarthria, ataxia, deafness and constriction of the visual field were the main symptoms. Emotional lability in the form of euphoria or 
depression was also common. Serious cases displayed states of mental confusion, drowsiness and stupor ${ }^{44-47}$. Sometimes, however, the victims were restless and prone to shouting, which was often followed by coma.

In the infant cases following fetal exposure, a cerebral palsy like syndrome was observed ${ }^{21,22)}$. Examination of these children revealed the following signs and symptoms at high frequency: mental retardation, cerebellar ataxia, primitive reflex and dysarthria, seizure, and pyramidal signs. Sensory disturbance, constriction of the visual fields and hearing impairment could not be assessed due to the serious conditions of the patients.

\section{Effects of in utero methylmercury exposure}

As mentioned above, in the Iraqi outbreak fetal cases were examined more closely ${ }^{24-27,48)}$. A group of mother and infant pairs were examined for the delay in developmental milestones such as walking and talking and the mothers' exposure to mercury, with the hair mercury content of each mother analyzed to determine the peak mercury concentration during pregnancy. Statistical analysis established a doseresponse relationship between the peak mercury concentration during pregnancy and whether first walking or talking was observed or not at the age of 18 or 24 months ${ }^{48-50)}$. Based on this dose-response relationship, $\mathrm{WHO}^{51)}$ claimed that "A prudent interpretation of the Iraqi data implies that a 5\% risk may be associated with the peak mercury level of 10 $20 \mu / g$ in maternal hair."

Epidemiological prospective studies with more sophisticated examination methods have been carried out since the mid 1980s.

A study performed in New Zealand investigated the development of children who had prenatal exposure to methylmercury by mothers' consumption of fish meals during pregnancy ${ }^{52,53)}$. The children were tested at the age of four using the Denver Developmental Screen Test (DDST), which is a standardized test of a child's mental development consisting of four major function sectors: gross motor, fine motor, language and personal-social. A developmental delay in an individual item is determined when the child has failed in his/her response and at least $90 \%$ of children can pass this item at a younger age. The prevalence for developmental delay was $52 \%$ in children whose mothers had been exposed to high levels of mercury and $17 \%$ in the reference group.

In a follow-up study at the age of six, each child was tested with the Test of Language Development (TOLD), the Wechsler Intelligence Scale for Children and the McCarthy Scale of Children's Abilities ${ }^{53}$. A principal finding was that high prenatal methylmercury exposure decreased performance in the tests, but contributed only little to the variation in test results, with ethnic background and social class having greater influence.

In the Seychelles Islands, the developmental effects of low level methylmercury exposure in utero from consumption of marine fish by mothers have also been studied ${ }^{54-66)}$. An association between in utero mercury exposure was found for DDST-R(evised) abnormal plus questionable scores combined $^{62)}$. A subset of this group of children were administered the McCarthy Scales of Children's Abilities, the Preschool Language Scale, and the Letter-Word Recognition and Applied Problems subtests of the WoodcockJohnson (W-J) Tests of Achievement that were appropriate to the children's age. Mercury exposure (measured as maternal hair mercury concentration) was negatively associated with four endpoints: The McCarthy General Cognitive Index and Perceptual Performance subscale; and the Preschool Language Scale Total Language and Auditory Comprehension subscale. When statistically determined outliers and points considered to be influential were removed from the analyses, statistical significance of the association remained only for auditory comprehension.

The main study, which was designed to be prospective and involved 779 mother-child pairs, followed ${ }^{61)}$. This study involved evaluation of children at 6.5, 19, 26 and 66 months of age. Age-appropriate tests administered included the following: Infantest (or Fagan's test of visual recognition memory), Bayley Scales of Infant Development (BSID), McCarthy Scales of Children's Abilities, the Preschool Language Scale and the DDST (6.5 months only). No association with maternal hair mercury was found for any of six endpoints in the children tested at six months. No effects of mercury exposure were seen in the outcome of five test endpoints at 19 months. Investigation at 66 months did not reveal the deviation associated with in utero mercury exposure for the following tests: McCarthy Scales of Children's Abilities in General Cognitive Index, Preschool Language Scale, Letter-Word Recognition of W-J Tests of Achievement, Applied Problems of W-J Tests of Achievement, Bender Gestalt test and Total T score from the Child Behavior Checklist. The analysis was adjusted for possible confounding factors including birth weight, the rank of birth, sex, medical records of the infants, age of the mother, alcohol consumption and smoking habits during pregnancy, and socioeconomic status.

The overall conclusion of the studies published to date is that it is yet unclear whether an association exists between low level mercury exposure of the mother and neurologic deficits in the child. The authors cautioned in several papers 
that subtle neurologic and neurobehavioral effects are more likely to be detected in older rather than younger children. The overall conclusion of the authors was that their results require careful interpretation, and that an association between relatively low level mercury exposure in utero and neurologic deficits has not been conclusively demonstrated ${ }^{66}$.

Another large study was initiated in the Faeroe Islands in $1986^{67-76)}$. Increased mercury exposure was largely attributed to the eating of pilot whale ${ }^{68}$. The subjects consisted of a group of 917 (of an initial cohort of 1022) children. They were evaluated for their neurophysiological and neuropsychological performances at about 7 years of age. Mercury in maternal hair and cord blood was analyzed, and a subset of cords was determined for $\mathrm{PCBs}{ }^{73)}$.

At seven years children received an examination including a functional neurological examination which emphasized motor coordination and perceptual-motor performance ${ }^{71,73)}$. Neurophysiological tests included the following: patternreversal visual evoked potentials; brainstem auditory evoked potentials; and postural sway. Neuropsychological tests included the Neurobehavioral Evaluation System (NES); Tactual Performance Test; Wechsler Intelligence Scale for Children-revised; Bender Visual Motor Gestalt Test; Boston Naming Test; California Verbal Learning Test; Nonverbal Analogue Profile of Mood States.

Although the neurophysiological tests showed no indication of mercury-associated dysfunction, significant negative associations were seen on several neuropsychological tests. Even with inclusion of covariates with uncertain influence on these tests results, multiple regression analysis indicated that $9 / 20$ measures showed mercury related decrements. The authors concluded that in utero exposure to methylmercury affects several domains of cerebral function ${ }^{73)}$.

The results of these studies are controversial, especially when comparing those of Seychelles and Faeroe Islands. In both studies, doses were principally indicated by mothers' hair mercury concentration and the difference between both the doses is small. The study designs and test-batteries were similar but not identical. The main difference between the two studies was the source of methylmercury exposure; in the Seychelles by consumption of ocean fish and in the Faeroe Islands blubber (pilot whale fat). One explanation is that contamination by PCBs and possibly dioxins may confound the results of the Faeroe island study.

\section{Exposure Markers and Occupational Exposure Limits (OEL)}

Blood and urine are common samples by which to assess occupational mercury exposure, whereas hair is considered the best indicator for environmental exposure to methylmercury.

\section{Exposure markers for elemental mercury}

In workers chronically exposed to mercury vapor, a good correlation has been observed between intensity of exposure and blood mercury concentration at the end of a work shift ${ }^{77}$. Mercury in the blood peaks rapidly, however, and decreases with an initial half-life of approximately two to four days ${ }^{78}$. Thus, evaluation of blood mercury is of limited value if a substantial amount of time has elapsed since exposure. Without selective determination for organic and inorganic mercury (and this is usually the case), dietary methylmercury also contributes substantially to the amount of mercury measured in blood at low levels of elemental mercury exposure, limiting the sensitivity of this biomarker.

For most occupational exposure events, urinary mercury has been used to estimate exposure. The toxicokinetics of mercury in urine is much slower than in blood: urinary mercury peaks approximately $2-3$ weeks after exposure and decreases at a half-life of 40-60 days for short-term exposures and 90 days for long-term exposures ${ }^{79,80}$. Therefore, urine is a more appropriate indicator for longer exposures than blood. Moreover, little dietary methylmercury is excreted in the urine, rendering the contribution of ingested methylmercury less significant. Although good correlation has been observed between urinary mercury levels and air levels of mercury vapor, such correlation was obtained after adjusting data for creatinine or specific gravity and after standardizing the amount of time elapsed after exposure ${ }^{77)}$, as considerable intra- and inter-individual variability has been observed in the urinary excretion rate ${ }^{81,82}$.

Exhaled air has been suggested as a possible biomarker of exposure to elemental mercury vapor because a portion of absorbed mercury vapor is excreted via the lungs. However, at low levels of exposure, mercury vapor released from dental amalgam may contribute substantially to the measured amount of mercury ${ }^{83)}$.

The amount of exhaled mercury is surprisingly high after ingestion of alcoholic beverages ${ }^{84}$, most likely because mercury is repeatedly oxidized and reduced in the body ${ }^{85-87)}$ and ethanol is believed to inhibit the activity of catalase, the principal oxidizing pathway. Consequently, this inhibition leads to relatively more reduction of ionic mercury and to 
an increase in elemental mercury in tissue and blood stream. Mercury vapor thus generated is exhaled via the lungs ${ }^{88-911}$. A pilot study clearly showed that exhaled mercury was increased by ingestion of ethanol among the ex-mercury workers but quantitative estimation was not performed (Satoh et al. unpublished data).

\section{Exposure markers for methylmercury}

Blood and scalp hair are the primary indicators used to assess methylmercury exposure. Methylmercury freely distributes throughout the body, and thus blood is a good indicator medium for estimating methylmercury exposure. Blood levels may not necessarily reflect mercury intake over time though, as levels fluctuate with dietary intake ${ }^{92,93)}$. Blood hematocrit and mercury concentration may be measured in both whole blood and plasma/serum, allowing the red blood cell to plasma mercury ratio to be determined, and interference from exposure to elemental or inorganic mercury to be estimated.

Scalp hair is also a good indicator for estimating methylmercury exposure ${ }^{28}$. Methylmercury is incorporated into scalp hair at the hair follicle in proportion to its content in blood. The hair-to-blood ratio in humans has been estimated as approximately 250-300: 1 expressed as microgram $\mathrm{Hg} / \mathrm{g}$ hair to $\mathrm{mg} \mathrm{Hg} / \mathrm{L}$ blood. However, some difficulties in measurement do arise, such as, inter-individual variation in body burden, differences in hair growth rates, and variations in fresh and saltwater fish intake, led to varying estimates $^{29,94)}$.

Methylmercury is stable once incorporated into hair, and therefore the mercury concentration in hair gives a longitudinal history of blood methylmercury levels ${ }^{28,51}$. Analysis of hair mercury levels may be confounded by adsorption of mercury vapor onto the hair strands ${ }^{95}$. However, inorganic mercury incorporation into hair is negligible. Artificial hair-waving decrease mercury levels in hair due to breaking down methylmercury into inorganic mercury ${ }^{96)}$.

\section{Occupational exposure limit}

Occupational exposure limits (OEL) for mercury vapor have been established in Japan and other countries. The Japan Society for Occupational Health (JSOH) recommended the OEL for mercury vapor to be $0.025 \mathrm{mg} / \mathrm{m}^{3}$ in 1998 . The American Congress of Governmental Industrial Hygienists (ACGIH) also recommended the same TLV. Other recommendations are as follows:

- ARAB Republic of Egypt TWA $0.05 \mathrm{mg} / \mathrm{m}^{3}$
- AUSTRIA MAK $0.005 \mathrm{ppm}\left(0.05 \mathrm{mg} / \mathrm{m}^{3}\right)$

- AUSTRALia TWA $0.1 \mathrm{mg} / \mathrm{m}^{3}$; Skin

- BELGIUM TWA $0.1 \mathrm{mg} / \mathrm{m}^{3}$; Skin

- DENMARK TWA $0.05 \mathrm{mg}(\mathrm{Hg}) / \mathrm{m}^{3}$, Skin

- FINLAND TWA $0.05 \mathrm{mg} / \mathrm{m}^{3}$

- HUNGARY TWA $0.02 \mathrm{mg} / \mathrm{m}^{3}$; STEL $0.04 \mathrm{mg} / \mathrm{m}^{3}$

- SWEDEN TWA $0.05 \mathrm{mg} / \mathrm{m}^{3}$ (vapor)

- POLAND MAC (TWA) vapors $0.025 \mathrm{mg} / \mathrm{m}^{3}$, MAC (STEL) vapors $0.2 \mathrm{mg} / \mathrm{m}^{3}$

- SWITZERLAND TWA $0.005 \mathrm{ppm}\left(0.05 \mathrm{mg} / \mathrm{m}^{3}\right)$; Skin (vapor)

- TURKEY TWA $0.1 \mathrm{mg} / \mathrm{m}^{3}$; Skin

Biological exposure indices (BEI) have also been established. JSOH recommends a mercury level of $35 \mu \mathrm{g} / \mathrm{g}$ creatinine in urine samples for biological monitoring. ACGIH have BEIs of $15 \mu \mathrm{g} / \mathrm{L}$ in blood sampled at the end of a shift at the end of a work week, and of $35 \mu \mathrm{g} / \mathrm{g}$ creatinine in preshift urine samples.

A lower OEL of methylmercury $\left(0.01 \mathrm{mg} \mathrm{Hg} / \mathrm{m}^{3}\right)$ has been established in most countries including Japan:

- ACGIH TLV-TWA $0.01 \mathrm{mg}(\mathrm{Hg}) / \mathrm{m}^{3} ;$ STEL $0.03 \mathrm{mg} / \mathrm{m}^{3}$

- AUSTRALIA TWA $0.01 \mathrm{mg}(\mathrm{Hg}) / \mathrm{m}^{3}$; STEL 0.03 $\mathrm{mg}(\mathrm{Hg}) / \mathrm{m}^{3}$; Skin

- AUSTRIA MAK $0.01 \mathrm{mg} / \mathrm{m}^{3}$, Skin

- BELGIUM TWA $0.01 \mathrm{mg}(\mathrm{Hg}) / \mathrm{m}^{3}$; STEL $0.03 \mathrm{mg}(\mathrm{Hg}) /$ $\mathrm{m}^{3}$; SKIN

- DENMARK TWA $0.05 \mathrm{mg}(\mathrm{Hg}) / \mathrm{m}^{3}$, Skin

- FINLAND TWA $0.01 \mathrm{mg}(\mathrm{Hg}) / \mathrm{m}^{3}$; Skin

- GERMANY TWA $0.01 \mathrm{mg} / \mathrm{m}^{3}$; Skin

- THE NETHERLANDS TWA $0.01 \mathrm{mg}(\mathrm{Hg}) / \mathrm{m}^{3}$; STEL $0.02 \mathrm{mg}(\mathrm{Hg}) / \mathrm{m}^{3}$; Skin

- THE PHILIPPINES TWA $0.01 \mathrm{mg}(\mathrm{Hg}) / \mathrm{m}^{3}$

- SWEDEN TWA $0.01 \mathrm{mg}(\mathrm{Hg}) / \mathrm{m}^{3} ;$ Skin

- SWITZERLAND TWA $0.01 \mathrm{mg} / \mathrm{m}^{3}$; Skin

- THAILAND TWA $0.01 \mathrm{mg}(\mathrm{Hg}) / \mathrm{m}^{3}$; STEL 0.04 $\mathrm{mg}(\mathrm{Hg}) / \mathrm{m}^{3}$

- TURKEY TWA $0.01 \mathrm{mg}(\mathrm{Hg}) / \mathrm{m}^{3}$; Skin

- UNITED KINGDOM TWA $0.01 \mathrm{mg}(\mathrm{Hg}) / \mathrm{m}^{3} ;$ STEL $0.03 \mathrm{mg}(\mathrm{Hg}) / \mathrm{m}^{3} ;$ Skin

These values are only applicable to occupational exposure and no known exposure limits for general populations have been established.

\section{Reference values}

Reference values for total mercury concentrations in biological media for the general population have been determined and set at: whole blood $1-8 \mu \mathrm{g} / \mathrm{L}^{97}$. As discussed 
above, exposure to methylmercury is predominantly due to fish consumption. Therefore, reference values differ according to fish consumption ${ }^{98}$ : No fish meals; $2.0 \mu \mathrm{g} / \mathrm{L}$, 2 meals/week; $4.8 \mu \mathrm{g} / \mathrm{L}, 2-4$ meals/week; $8.4 \mu \mathrm{g} / \mathrm{L}$, more than 4 meals/week; $44.4 \mu \mathrm{g} / \mathrm{L}$.

The reference value for urine is $4-5 \mu \mathrm{g} / \mathrm{L}^{99)}$. For scalp hair, $2 \mu \mathrm{g} / \mathrm{g}$ has been indexed by $\mathrm{WHO}^{97)}$, with the limits depending on fish consumption: once/month; $1.4 \mu \mathrm{g} / \mathrm{g}$, once/ $2 \mathrm{wk} ; 1.9 \mu \mathrm{g} / \mathrm{g}$, once/wk; $2.5 \mu \mathrm{g} / \mathrm{g}$, once/day $11.6 \mu \mathrm{g} / \mathrm{g}^{100)}$.

\section{References}

1) Clarkson TW (1997) The toxicology of mercury. Critical Reviews in Clinical Laboratory Sciences 34, 369-403.

2) Rahola T, Hattula T, Korolainen A, Miettinen JK (1973) Elimination of free and protein-bound ionic mercury $\left(20 \mathrm{Hg}^{2+}\right)$ in man. Annals of Clinical Research 5, 214 9.

3) Aberg B, Ekman L, Falk R, Greitz U, Persson G, Snihs JO (1969) Metabolism of methyl mercury $(203 \mathrm{Hg})$ compounds in man. Archives of Environmental Health 19, 478-84.

4) Nakamura H (1969) [Studies on the decomposition of organomercury compounds. II. Decomposition of phenylmercury acetate in vivo]. Kumamoto Igakkai Zasshi - Journal of the Kumamoto Medical Society 43, 994-1001.

5) Nakamura H (1969) [Studies on the decomposition of organomercury compounds. 3. Decomposition of phenylmercury acetate in vitro]. Kumamoto Igakkai Zasshi - Journal of the Kumamoto Medical Society 43, 1002-10.

6) Yonaha M, Ishikura S, Uchiyama M (1975) Toxicity of organic mercury compounds. III. Uptake and retention of mercury in several organs of mice by long term exposure of alkoxyethylmercury compounds. Chemical \& Pharmaceutical Bulletin 23, 1718-25.

7) Yonaha M, Ishikura S, Uchiyama M (1975) Toxicity of organic mercury compounds. IV. Metabolism and excretion of alkoxyethylmercury compounds in mice. Chemical \& Pharmaceutical Bulletin 23, 1726-32.

8) Branches FJ, Erickson TB, Aks SE, Hryhorczuk DO (1993) The price of gold: mercury exposure in the Amazonian rain forest. Journal of Toxicology - Clinical Toxicology 31, 295-306.

9) Heckmann J, Broomberg J (1991) Mercury intoxication as a result of illicit gold smelting [letter]. South African Medical Journal 79, 51.
10) Bidone ED, Castilhos ZC, Cid de Souza TM, Lacerda LD (1997) Fish contamination and human exposure to mercury in the Tapajos River Basin, Para State, Amazon, Brazil: A screening approach. Bull. Environ. Contam. Toxicol. 59, 194-201.

11) Castilhos ZC, Bidone ED, Lacerda LD (1998) Increase of the background human exposure to mercury through fish consumption due to gold mining at the Tapajos River Region, Para State, Amazon. Bulletin of Environmental Contamination and Toxicology 61, 2029.

12) Kehrig HA, Malm O, Akagi H, Guimaraes JR, Torres JP (1998) Methylmercury in fish and hair samples from the Balbina Feservoir, Brazilian Amazon. Environ Res 77, 84-90.

13) Dangwal SK (1993) Evaluation and control of mercury vapor exposure in the cell house of chlor alkali plants. Environmental Research 60, 254-8.

14) Geelhoed GW (1978) The record of an early mercurial cure in the history of syphilis, with a case history of a 29-year-old white male Renaissance genius [Benvenuto Cellini]. Australian \& New Zealand Journal of Surgery 48, 589-94.

15) Nylander M, Friberg L, Lind B (1987) Mercury concentrations in the human brain and kidneys in relation to exposure from dental amalgam fillings. Swedish Dental Journal 11, 179-87.

16) Berdouses E, Vaidyanathan TK, Dastane A, Weisel C, Houpt M, Shey Z (1995) Mercury release from dental amalgams: an in vitro study under controlled chewing and brushing in an artificial mouth. Journal of Dental Research 74, 1185-93.

17) Gay DD, Cox RD, Reinhardt JW (1979) Chewing releases mercury from fillings [letter]. Lancet 1, 9856.

18) Mackert JR, Jr., Berglund A (1997) Mercury exposure from dental amalgam fillings: absorbed dose and the potential for adverse health effects. Crit Rev Oral Biol Med 8, 410-36.

19) Hunter D (1969) Mercury. In: The disease of occupations. 5th ed. eds. by Hunter D, 288-332, The English Universities Press LTD., London.

20) Watanabe C, Satoh H (1996) Evolution of our understanding of methylmercury as a health threat. Environmental Health Perspectives 104, 367-79.

21) Harada M (1978) Congenital Minamata disease: intrauterine methylmercury poisoning. Teratology 18, 285-8.

22) Harada M (1979) Congenital (or fetal) Minamata 
disease. In: Minamata Disease-Studies during these 20 years and prblems remained for today (in Japanese, translated by the present author). eds. by Arima S, 34563, Seirinsha, Tokyo.

23) Bakir F, Damluji SF, Amin-Zaki L, Murtadha M, Khalidi A, al-Rawi NY, Tikriti S, Dahahir HI, Clarkson TW, Smith JC, Doherty RA (1973) Methylmercury poisoning in Iraq. Science 181, 230-41.

24) Amin-Zaki L, Elhassani S, Majeed MA, Clarkson TW, Doherty RA, Greenwood M (1974) Intra-uterine methylmercury poisoning in Iraq. Pediatrics 54, 58795.

25) Amin-Zaki L, Elhassani S, Majeed MA, Clarkson TW, Doherty RA, Greenwood MR, Giovanoli-Jakubczak T (1976) Perinatal methylmercury poisoning in Iraq. American Journal of Diseases of Children 130, 10706.

26) Amin-zaki L, Majeed MA, Clarkson TW, Greenwood MR (1978) Methylmercury poisoning in Iraqi children: clinical observations over two years. British Medical Journal 1, 613-6.

27) Amin-Zaki L, Majeed MA, Greenwood MR, Elhassani SB, Clarkson TW, Doherty RA (1981) Methylmercury poisoning in the Iraqi suckling infant: a longitudinal study over five years. Journal of Applied Toxicology 1, 210-4.

28) Phelps RW, Clarkson TW, Kershaw TG, Wheatley B (1980) Interrelationships of blood and hair mercury concentrations in a North American population exposed to methylmercury. Archives of Environmental Health 35, 161-8.

29) Skerfving S (1974) Methylmercury exposure, mercury levels in blood and hair, and health status in Swedes consuming contaminated fish. Toxicology 2, 3-23.

30) Jensen S, Jernelov A (1969) Biological methylation of mercury in aquatic organisms. Nature 223, 753-4.

31) WHO (1990) Effects on Man. In: Environmental health criteria 101: Methylmercury. 68-99, World Health Organization, Geneva.

32) Kurisaki E, Sato M, Asano S, Gunji H, Mochizuki M, Odajima H, Wakasa H, Satoh H, Watanabe C, Hiraiwa $\mathrm{K}$ (1999) Insufficient metallothionein synthesis in the lung and kidney in human acute inorganic mercury poisoning. Journal of Health Science 45, 309-17.

33) Roels H, Gennart JP, Lauwerys R, Buchet JP, Malchaire J, Bernard A (1985) Surveillance of workers exposed to mercury vapour:validation of a previously proposed biological threshold limit value for mercury concentration in urine. American Journal of Industrial
Medicine 7, 45-71.

34) Langworth $S$, Almkvist $O$, Soderman E, Wikstrom $B O$ (1992) Effects of occupational exposure to mercury vapour on the central nervous system. British Journal of Industrial Medicine 49, 545-55.

35) Barregard L, Hultberg B, Schutz A, Sallsten G (1988) Enzymuria in workers exposed to inorganic mercury. International Archives of Occupational \& Environmental Health 61, 65-9

36) Chapman LJ, Sauter SL, Henning RA, Dodson VN, Reddan WG, Matthews CG (1990) Differences in frequency of finger tremor in otherwise asymptomatic mercury workers. British Journal of Industrial Medicine 47, 838-43.

37) Fawer RF, de Ribaupierre Y, Guillemin MP, Berode M, Lob M (1983) Measurement of hand tremor induced by industrial exposure to metallic mercury. British Journal of Industrial Medicine 40, 204-8.

38) Piikivi L, Tolonen U (1989) EEG findings in chloralkali workers subjected to low long term exposure to mercury vapour. British Journal of Industrial Medicine 46, 370-5.

39) Ngim CH, Foo SC, Boey KW, Jeyaratnam J (1992) Chronic neurobehavioural effects of elemental mercury in dentists. British Journal of Industrial Medicine 49, 782-90.

40) Albers JW, Kallenbach LR, Fine LJ, Langolf GD, Wolfe RA, Donofrio PD, Alessi AG, Stolp-Smith KA, Bromberg MB (1988) Neurological abnormalities associated with remote occupational elemental mercury exposure. Annals of Neurology 24, 651-9.

41) Kishi R, Doi R, Fukuchi Y, Satoh H, Satoh T, Ono A, Moriwaka F, Tashiro K, Takahata N, The Mercury Workers Study Group (1994) Residual neurobehavioural effects associated with chronic exposure to mercury vapour. Occupational \& Environmental Medicine 51, $35-41$.

42) Barregard L, Hogstedt B, Schutz A, Karlsson A, Sallsten G, Thiringer G (1991) Effects of occupational exposure to mercury vapor on lymphocyte micronuclei. Scand J Work Environ Health 17, 263-8.

43) Hunter D, Russell D (1954) Focal cerebral and cerebellar atrophy in a human subject due to organic mercury compounds. J Neurol Neurosurg Psychiatry 17, 235-41.

44) Tokuomi H (1979) Clinical investigation of Minamata disease. In: Minamata Disease-Studies during these 20 years and problems remained for today (in Japanese, translated by the present authors). eds. by Arima S, 273- 
88, Seirinsha, Tokyo.

45) Tokuomi H (1968) [Minamata disease]. Naika - Internal Medicine 21, 864-70.

46) Tokuomi H, Okajima T (1969) [Clinical aspects of Minamata disease]. Shinkei Kenkyu No Shimpo Advances in Neurological Sciences 13, 69-75.

47) Tokuomi H, Uchino M, Imamura $S$, Yamanaga $H$, Nakanishi R, Ideta T (1982) Minamata disease (organic mercury poisoning): neuroradiologic and electrophysiologic studies. Neurology 32, 1369-75.

48) Cox C, Marsh D, Myers G, Clarkson T (1995) Analysis of data on delayed development from the 1971-72 outbreak of methylmercury poisoning in Iraq: assessment of influential points. Neurotoxicology 16, 727-30.

49) Marsh DO, Myers GJ, Clarkson TW, Amin-Zaki L, Tikriti S, Majeed MA (1980) Fetal methylmercury poisoning: clinical and toxicological data on 29 cases. Annals of Neurology 7, 348-53.

50) Cox C, Clarkson TW, Marsh DO, Amin-Zaki L, Tikriti S, Myers GG (1989) Dose-response analysis of infants prenatally exposed to methyl mercury: an application of a single compartment model to single-strand hair analysis. Environmental Research 49, 318-32.

51) WHO (1990) Summary and Conclusions. In: Environmental health criteria 101: Methylmercury. 117, World Health Organization, Geneva.

52) Kjellstrom T, Kennedy P, Wallis S, Mantell C (1986) Report 3080. National Swedish Environmental Protection Board, Solna, Sweden.

53) Kjellstrom T, Kennedy P, Wallis S, Mantell C (1989) Report 3642. National Swedish Environmental Protection Board, Solna, Sweden.

54) Axtell CD, Myers GJ, Davidson PW, Choi AL, Cernichiari E, Sloane-Reeves J, Shamlaye C, Cox C, Clarkson TW (1998) Semiparametric modeling of age at achieving developmental milestones after prenatal exposure to methylmercury in the Seychelles Child Development Study. Environmental Health Perspectives 106, 559-64.

55) Matthews AD (1983) Mercury content of commercially important fish of the Seychelles, and hair mercury levels of a selected part of the population. Environmental Research 30, 305-12.

56) Marsh DO, Clarkson TW, Myers GJ, Davidson PW, Cox C, Cernichiari E, Tanner MA, Lednar W, Shamlaye C, Choisy O, Hoareau C, Berlin M (1995) The Seychelles study of fetal methylmercury exposure and child development: introduction. Neurotoxicology 16,
583-96.

57) Myers GJ, Davidson PW, Cox C, Shamlaye CF, Tanner MA, Marsh DO, Cernichiari E, Lapham LW, Berlin M, Clarkson TW (1995) Summary of the Seychelles child development study on the relationship of fetal methylmercury exposure to neurodevelopment. Neurotoxicology 16, 711-16.

58) Davidson PW, Myers GJ, Cox C, Shamlaye CF, Marsh DO, Tanner MA, Berlin M, Sloane-Reeves J, Cernichiari E, Choisy O, Choi A, Clarkson TW (1995) Longitudinal neurodevelopmental study of Seychellois children following in utero exposure to methylmercury from maternal fish ingestion: outcomes at 19 and 29 months. Neurotoxicology 16, 677-88.

59) Shamlaye CF, Marsh DO, Myers GJ, Cox C, Davidson PW, Choisy O, Cernichiari E, Choi A, Tanner MA, Clarkson TW (1995) The Seychelles child development study on neurodevelopmental outcomes in children following in utero exposure to methylmercury from a maternal fish diet: background and demographics. Neurotoxicology 16, 597-612.

60) Davidson PW, Myers GJ, Cox C, Shamlaye C, Choisy O, Sloane-Reeves J, Cernichiari E, Marsh DO, Berlin M, Tanner M, Clarkson TW (1995) Neurodevelopmental test selection, administration, and performance in the main Seychelles child development study. Neurotoxicology 16, 665-76.

61) Myers GJ, Marsh DO, Davidson PW, Cox C, Shamlaye CF, Tanner M, Choi A, Cernichiari E, Choisy O, Clarkson TW (1995) Main neurodevelopmental study of Seychellois children following in utero exposure to methylmercury from a maternal fish diet: outcome at six months. Neurotoxicology 16, 653-64.

62) Myers GJ, Davidson PW, Cox C, Shamlaye CF, Tanner MA, Choisy O, Sloane-Reeves J, Marsh D, Cernichiari E, Choi A, Berlin M, Clarkson TW (1995) Neurodevelopmental outcomes of Seychellois children sixty-six months after in utero exposure to methylmercury from a maternal fish diet: pilot study. Neurotoxicology 16, 639-52.

63) Myers GJ, Marsh DO, Cox C, Davidson PW, Shamlaye CF, Tanner MA, Choi A, Cernichiari E, Choisy O, Clarkson TW (1995) A pilot neurodevelopmental study of Seychellois children following in utero exposure to methylmercury from a maternal fish diet. Neurotoxicology 16, 629-38.

64) Myers GJ, Davidson P, Cox C, Shamlaye C, Choisy O, Cernichiari E, Choi A, Sloane-Reeves J, Axtell C, Gao P, Clarkson TW (1997) The Seychelles child 
development study: Results and new directions through twenty-nine months. Water Air and Soil Pollution 97, 53-61.

65) Myers GJ, Davidson PW, Shamlaye CF, Axtell CD, Cernichiari E, Choisy O, Choi A, Cox C, Clarkson TW (1997) Effects of prenatal methylmercury exposure from a high fish diet on developmental milestones in the Seychelles Child Development Study. NeuroToxicology 18, 819-30.

66) Davidson PW, Myers GJ, Cox C, Axtell C, Shamlaye C, Sloane-Reeves J, Cernichiari E, Needham L, Choi A, Wang Y, Berlin M, Clarkson TW (1998) Effects of prenatal and postnatal methylmercury exposure from fish consumption on neurodevelopment: Outcomes at 66 months of age in the Seychelles child development study. Journal of the American Medical Association 280, 701-7.

67) Grandjean $P$, Weihe $P(1993)$ Neurobehavioral effects of intrauterine mercury exposure: potential sources of bias. Environmental Research 61, 176-83.

68) Grandjean P, Weihe P, Jorgensen PJ, Clarkson T, Cernichiari E, Videro T (1992) Impact of maternal seafood diet on fetal exposure to mercury, selenium, and lead. Archives of Environmental Health 47, 18595.

69) Grandjean P, Weihe P, Needham LL, Burse VW, Patterson DG, Jr., Sampson EJ, Jorgensen PJ, Vahter M (1995) Relation of a seafood diet to mercury, selenium, arsenic, and polychlorinated biphenyl and other organochlorine concentrations in human milk. Environmental Research 71, 29-38.

70) Grandjean P, Weihe P, Nielsen JB (1994) Methylmercury: significance of intrauterine and postnatal exposures. Clinical Chemistry 40, 1395-400.

71) Grandjean P, Weihe P, White R, Debes F (1998) Cognitive performance of children prenatally exposed to "safe" levels of methylmercury. Environmental Research 77, 165-72.

72) Grandjean P, Weihe P, White RF (1995) Milestone development in infants exposed to methylmercury from human milk. Neurotoxicology 16, 27-33.

73) Grandjean P, Weihe P, White RF, Debes F, Araki S, Yokoyama K, Murata K, Sorensen N, Dahl R, Jorgensen PJ (1997) Cognitive deficit in 7-year-old children with prenatal exposure to methylmercury. Neurotoxicology and Teratology 19, 417-28.

74) Grandjean P (1997) Mercurial uncertainties in environmental health. Annals of the New York Academy of Sciences 837, 239-45.
75) Grandjean P (1997) Adverse health effects of transplacental exposure to environmental pollutants. Placenta 18, A3.

76) Weihe P, Grandjean P, Debes F, White R (1996) Health implications for Faroe islanders of heavy metals and PCBs from pilot whales. Science of the Total Environment 186, 141-8.

77) Roels H, Abdeladim S, Ceulemans E, Lauwerys R (1987) Relationships between the concentrations of mercury in air and in blood or urine in workers exposed to mercury vapour. Annals of Occupational Hygiene 31, 135-45.

78) Cherian MG, Hursh JB, Clarkson TW, Allen J (1978) Radioactive mercury distribution in biological fluids and excretion in human subjects after inhalation of mercury vapor. Archives of Environmental Health 33, 109-14.

79) Roels HA, Boeckx M, Ceulemans E, Lauwerys RR (1991) Urinary excretion of mercury after occupational exposure to mercury vapour and influence of the chelating agent meso-2,3-dimercaptosuccinic acid (DMSA). British Journal of Industrial Medicine 48, 247-53.

80) Barregard L, Sallsten G, Schutz A, Attewell R, Skerfving S, Jarvholm B (1992) Kinetics of mercury in blood and urine after brief occupational exposure. Archives of Environmental Health 47, 176-84.

81) Barber TE, Wallis G (1986) Correction of urinary mercury concentration by specific gravity, osmolality, and creatinine. Journal of Occupational Medicine 28, 354-9.

82) Piotrowski JK, Trojanowska B, Mogilnicka EM (1975) Excretion kinetics and variability of urinary mercury in workers exposed to mercury vapour. International Archives of Occupational \& Environmental Health 35, 245-6.

83) Berglund A (1992) Release of mercury vapor from dental amalgam. Swedish Dental Journal - Supplement 85, $1-52$.

84) Kudsk FN (1965) The influence of ethyl alcohol on the absorption of mercury vapour from the lungs in man. Acta Pharmacologica et Toxicologica 23, 26374.

85) Sugata Y, Halbach S, Allen J, Clarkson TW (1979) Tissue distribution of inhaled mercury vapor in acatalasemic mice. Journal of Environmental Science \& Health - Part C: Environmental Health Sciences 13, 97-106.

86) Magos L, Halbach S, Clarkson TW (1978) Role of 
catalase in the oxidation of mercury vapor. Biochemical Pharmacology 27, 1373-7.

87) Halbach S, Clarkson TW (1978) Enzymatic oxidation of mercury vapor by erythrocytes. Biochimica et Biophysica Acta 523, 522-31.

88) Dunn JD, Clarkson TW, Magos L (1981) Interaction of ethanol and inorganic mercury: generation of mercury vapor in vivo. Journal of Pharmacology \& Experimental Therapeutics 216, 19-23.

89) Dunn JD, Clarkson TW, Magos L (1978) Ethanolincreased exhalation of mercury in mice. British Journal of Industrial Medicine 35, 241-4.

90) Dunn JD, Clarkson TW (1980) Does mercury exhalation signal demethylation of methylmercury? Health Physics 38, 411-4.

91) Dunn JD, Clarkson TW, Magos L (1981) Ethanol reveals novel mercury detoxification step in tissues. Science 213, 1123-5.

92) Sherlock JC, Quinn MJ (1988) Underestimation of dose-response relationship with particular reference to the relationship between the dietary intake of mercury and its concentration in blood. Human Toxicology 7, 129-32.

93) Sherlock JC, Lindsay DG, Hislop JE, Evans WH, Collier TR (1982) Duplication diet study on mercury intake by fish consumers in the United Kingdom. Archives of Environmental Health 37, 271-8.
94) Birke G, Johnels AG, Plantin LO, Sjostrand B, Skerfving S, Westermark T (1972) Studies on humans exposed to methyl mercury through fish consumption. Archives of Environmental Health 25, 77-91.

95) Francis PC, Birge WJ, Roberts BL, Black JA (1982) Mercury content of human hair: a survey of dental personnel. Journal of Toxicology \& Environmental Health 10, 667-72.

96) Yamamoto R, Suzuki T (1978) Effects of artificial hair-waving on hair mercury values. International Archives of Occupational \& Environmental Health 42, 1-9.

97) WHO (1990) Environmental Health Criteria 101: Methylmercury. World Health Organization, Geneva.

98) Brune D, Nordberg GF, Vesterberg O, Gerhardsson L, Wester PO (1991) A review of normal concentrations of mercury in human blood. Science of the Total Environment 100, 235-82.

99) Nordberg G, Brune D, Gerhardsson L, Grandjean P, Vesterberg O, Wester PO (1992) The ICOH and IUPAC international programme for establishing reference values of metals. Science of the Total Environment 120, 17-21.

100) Airey $D$ (1983) Total mercury concentrations in human hair from 13 countries in relation to fish consumption and location. Science of the Total Environment 31, 157-80. 